\title{
Assessment of Supplementation of Soy-Poha Ladoo for Prevention of Malnutrition in Rural Area of Ratlam District, India
}

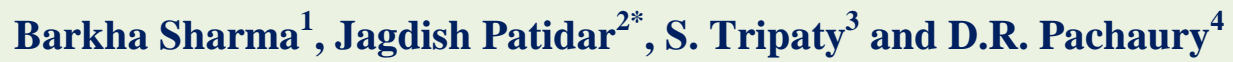 \\ ${ }^{1}$ SMS Home-Science, ${ }^{2}$ SRF-NICRA Project, ${ }^{3}$ Senior Scientist and Head, ${ }^{4}$ Farm Manager \\ Krishi Vigyan Kendra, Ratlam (M.P), India
}

\begin{tabular}{|c|}
\hline Keywords \\
\hline $\begin{array}{l}\text { Soyladoo, } \\
\text { Anthropometric } \\
\text { measurements }\end{array}$ \\
\hline Article Info \\
\hline $\begin{array}{l}\text { Accepted: } \\
04 \text { November } 2018 \\
\text { Available Online: } \\
10 \text { December } 2018\end{array}$ \\
\hline
\end{tabular}

A B S T R A C T
The food and nutrition security of the population has been the matter of concern world over. Problem in attaining food and nutrition security is prominent particularly in developing world. Protein calories malnutrition is major nutritional problem of the world. To treat malnutrition among the pre-school children the formulation of locally based protein rich product is must hence attempt was made to formulate soy based food product such as soy-poha ladoo. krishi vigyan Kendra Ratlam conduct a study during 2015-16 to 2017-18 on assessment of supplementation of soy-poha Ladoo to assess the effectiveness of protein and iron supplementation for improving protein energy malnutrition (PEM) on health of pre-school children in rural area of Ratlam district of MP. This product was evaluated for its major nutrient content like carbohydrate, energy, protein and fat. The 40 malnourished pre-school children of five anganwadies were selected by conducting camp are classified as two groups. In the present study soy-poha ladoo recorded highest height $(88.9 \mathrm{~cm})$, weight $(13.95 \mathrm{Kg})$ and BMI $(15.69)$ indicates positive effect of supplementation of locally available protein and iron rich food source like soybean and poha.

\section{Introduction}

Soybean has been identified as a low cost nutrition rich food raw material which has potential to help enhance the food availability with nutrition. The soybean has been honoured as a food raw material for incorporation in the diet of nutritionally poor segment. The fact that properly processed soybean also extends health benefits to consumers; it serves as a boon to the consumers in improving the health.

Children between one and five years of age remain at significant risk of under nutrition.
They are still growing rapidly but have not fully developed independent feeding skills in the earlier years of this era; they remain totally dependent on an adult. Sometimes growth failure may occur even in the presence of normal meal patterns because the energy density of the diet is inadequate. The nutritional problems which manifest as a result of malnutrition prior to and during the infancy and early childhood has an impact on health, general growth and development of children (Sarada and Mrudula, 2016).

According to Ghosh et al., (2006) nutritional problems like protein energy malnutrition, 
anemia and vitamin - A deficiency continue to plague a large proportion of Indian children. The diets and nutritional status of urban slum children in India is far away from being satisfactory. High prevalence of malnutrition among young children is also due to lack of awareness and knowledge regarding their food requirements and absence of a responsible adult care giver. Improving nutritional status of urban poor requires a more direct, more focused, and more integrated strategy.

Soybean is one of the most important legumes having more than 40 per cent protein combined with 20 per cent oil (Deshapande, 1990). It can be effectively used for supplementing cereals based products due to of its amino acids profile. Beside it has a good source of minerals, vitamins antioxidants and better neutral-citical properties (Ketarpau and Goyal, 2008). Soybean is a complete plant protein. Due to its high biological value and content good numbers of essential amino acids it can be use to prevent protein calorie malnutrition among vulnerable groups in the community (Ghatge, 2014).

Soybean was targeted to be used in India, as major protein source to meet nutritional requirements. soybean contains, other than $43 \%$ protein, $19.5 \%$ fat, $21 \%$ carbohydrate and provides $432 \mathrm{kcal}$ per $100 \mathrm{~g}$. Soybean can make significant nutritional contribution if typical traditional foods are supplemented with properly processed soybean in combination with cereals.

\section{Objective}

To assess the effectiveness of protein and iron supplementation for improving protein energy malnutrition on health of pre-school children.

Hence, by taking into account the different properties of soybean, it is considered to use for the soya ladoo supplementary food product. The data regarding formulation, preparation and evaluation of soya ladoo were collected.

\section{Materials and Methods}

This study was carried out during 2015-16 to 2017-18 at five angan wadies located at different location in Ratlam district of Madhya Pradesh (India). Wheat is the staple food of the district. In the present investigation, 40 malnourished pre-school children were selected by conducting camp and they were supplied with $100 \mathrm{~g}$ of soy-poha ladoo for 90 days with various food ingredients. The following treatments have been decided based on food supplemental diet provided to the same children for 90 days and considerable changes were noted accordingly.

\section{Soya ladoo}

The local varieties of soybean and Bengal gram were procured from the market. It was cleaned, washed, dried, coarsely grind, dehulled and made into flour separately by use of grinding machine. Soy-poha ladoo was prepared by use of appropriate formulations.

\section{Treatments}

1. $\mathrm{T}_{1^{-}}$daily diet (without providing supplements)

2. $\mathrm{T}_{2}$ - Provided with 100 grams of SoyaPoha Ladoo Daily (90 days)

First group of 20 children were not provided with any nutritional supplements i.e as on their daily diet intake, which were treated as control $\left(\mathrm{T}_{1}\right)$. The next group of 20 children was supplemented with 100 grams of soy-poha ladoo daily for 90 days. On the basis of nutritional composition of basic ingredients (Table 1), the nutritional content of soy-poha ladoo were estimated as presented in Table 2. From Table 2 it is seen that the $100 \mathrm{~g}$ of 
soy-poha ladoo contains $343.40 \mathrm{kcal}, 102.25 \mathrm{~g}$ fat, $6.87 \mathrm{~g}$ protein, $0.57 \mathrm{~g}$ Fiber, $63.40 \mathrm{mg}$ calcium and $8.26 \mathrm{mg}$ iron. Soy-poha ladoo prepared with combination of soybean flour, besan, ghee, poha and jagrgery, and supplied to subject through daily diet for 90 days. After 90 days anthropometric Measurements was recorded.

\section{Results and Discussion}

As the pre-school children were recognized as a priority target group and to increase their anthropometric measurement level was the aim of the present investigation, the effect of soy-poha ladoo prepared and supplied to the subjects was observed as recorded in Table 3. According to basic anthropometric measurement, data of the subjects is presented in table 3. The highest average height (88.55 $\mathrm{cm})$, weight (13.52kg) and BMI (15.27) was recorded after intervention and the per cent increase of height, weight and BMI is $0.62 \%$, $8.66 \%$ and $8.06 \%$ respectively as compared to before intervention $88.0 \mathrm{~cm}$ (height), $12.44 \mathrm{~kg}$ (weight) and 14.13 (BMI). Whereas among the treatment $\mathrm{T}_{2}$ recorded highest height $(88.9 \mathrm{~cm})$, weight $(13.95 \mathrm{Kg})$ and BMI (15.69) as compared to $\mathrm{T}_{1} 88.2 \mathrm{~cm}$ (Height), $13.10 \mathrm{Kg}$ (weight) and 14.85 (BMI) respectively after intervention. Within the treatment per cent increase of height $(0.90 \%)$, weight $(9.06 \%)$ and BMI (8.13\%) was significantly observed by $\mathrm{T}_{2}$, as compared to $\mathrm{T}_{1}(0.34 \%, 8.26 \%$ and $7.92 \%)$

Table.1 Composition and nutritional contents of basic ingredients for soy-poha ladoo

\begin{tabular}{|l|l|l|l|l|l|l|l|l|l|}
\hline Items & $\begin{array}{l}\text { Amt } \\
(\mathbf{g})\end{array}$ & $\begin{array}{l}\text { Energy } \\
(\mathbf{K c a l})\end{array}$ & $\begin{array}{l}\text { Fat } \\
(\mathbf{g})\end{array}$ & $\begin{array}{l}\text { Protein } \\
(\mathbf{g})\end{array}$ & $\begin{array}{l}\text { Fiber } \\
(\mathbf{g})\end{array}$ & $\begin{array}{l}\text { Calcium } \\
(\mathbf{m g})\end{array}$ & $\begin{array}{l}\text { Iron } \\
(\mathbf{m g})\end{array}$ & $\begin{array}{l}\text { Folic Acid } \\
(\mathbf{I U})\end{array}$ & $\begin{array}{l}\text { Vit.A } \\
(\text { IU) }\end{array}$ \\
\hline Poha & 200 & 692 & 2.4 & 13.2 & 1.4 & 40 & 40 & 73.2 & - \\
\hline Besan & 50 & 186 & 2.8 & 10.4 & 0.6 & 28 & 2.65 & 50 & 64.5 \\
\hline $\begin{array}{l}\text { Soybean } \\
\text { flour }\end{array}$ & 50 & 216 & 9.75 & 21.6 & 1.85 & 120 & 5.2 & 4.95 & 213 \\
\hline Jaggery & 300 & 1149 & 0.3 & 1.2 & - & 240 & 7.92 & - & - \\
\hline Ghee & 75 & 75 & 675 & - & - & - & - & - & - \\
\hline Total & 675 & 2318 & 690.25 & 46.4 & 3.85 & 428 & 55.77 & 128.15 & 277.5 \\
\hline
\end{tabular}

Table.2 Nutrient content of soy-poha ladoo per $100 \mathrm{~g}$

\begin{tabular}{|l|l|l|l|l|l|l|l|}
\hline $\begin{array}{l}\text { Energy } \\
\text { (kcal) }\end{array}$ & Fat (g) & Protein $(\mathrm{g})$ & Fiber $(\mathrm{g})$ & $\begin{array}{l}\text { Calcium } \\
(\mathrm{mg})\end{array}$ & Iron (mg) & $\begin{array}{l}\text { Folic acid } \\
\text { (IU) }\end{array}$ & Vit.A (IU) \\
\hline $\mathbf{3 4 3 . 4 0}$ & 102.25 & 6.87 & 0.57 & 63.40 & 8.26 & 18.98 & 4.11 \\
\hline
\end{tabular}

Table.3 Changes in Anthropometric Measurements

\begin{tabular}{|c|c|c|c|c|c|c|c|c|c|}
\hline \multirow{2}{*}{$\begin{array}{l}\text { RESULT } \\
\text { S }\end{array}$} & \multicolumn{3}{|c|}{ Height (cm) } & \multicolumn{3}{|c|}{ Weight (kg) } & \multicolumn{3}{|c|}{ BMI } \\
\hline & $\begin{array}{c}\text { Before } \\
\text { interventio } \\
\mathbf{n}\end{array}$ & $\begin{array}{c}\text { After } \\
\text { interventio } \\
n\end{array}$ & $\begin{array}{c}\% \\
\text { increas } \\
\mathrm{e}\end{array}$ & $\begin{array}{c}\text { Before } \\
\text { interventio } \\
\mathbf{n}\end{array}$ & $\begin{array}{c}\text { After } \\
\text { interventio } \\
\mathbf{n}\end{array}$ & $\begin{array}{c}\% \\
\text { increas } \\
\mathrm{e}\end{array}$ & $\begin{array}{c}\text { Before } \\
\text { interventio } \\
\mathbf{n}\end{array}$ & $\begin{array}{c}\text { After } \\
\text { interventio } \\
n\end{array}$ & $\begin{array}{c}\% \\
\text { increas } \\
\mathrm{e}\end{array}$ \\
\hline $\mathrm{T}_{1}$ & 87.9 & 88.2 & 0.34 & 12.10 & 13.10 & 8.26 & 13.76 & 14.85 & 7.92 \\
\hline $\mathrm{T}_{2}$ & 88.1 & 88.9 & 0.90 & 12.79 & 13.95 & 9.06 & 14.51 & 15.69 & 8.13 \\
\hline
\end{tabular}


Height, weight and BMI respectively shown in table 4 depict the height, weight and body mass index is higher than the traditional technology. Maximum increased height, weight and body mass index was observed with soy-poha ladoo.

In conclusion, results of the study clearly indicate positive effect of supplementation of locally available protein and iron rich food source like soybean and poha. However, the study gave encouraging results still more concentrated efforts are needed to arrive at conclusion on a large group. The children in growing age show increase in height, intake of nutritional supplementation and its acceptance and consumption by the children contributes to children growth and development. The nutritional supplementation to the experimental group for a period of 90 days contributed to increase in all the three anthropometric measurements: height, weight, body mass index. The control group children also showed increase in height, weight, body mass index but low growth rate. Which may also be attributed to regular nutritional supplementation in anganwadi centres. Yet the soy-poha ladoo proved to contribute in better nutrition of anganwadi children due to its nutritive value and acceptance as a low cost nutritional supplement it is suitable for anganwadi children.

\section{References}

Deshapande, S.D. (1990). Studies on some engineering aspect for processing and utilization of soybean. Ph.D Thesis, post harvest- technology centre. Indian Institute of Technology, Kharagpur, U.P. (India).

Ghatge, N.S. (2014). Study of nutritional composition analysis of soya based formulated food products. Food Sci. Res. J. 5(1): 7-10.

Khetarpaul, N. and Goyal, R. (2008). Development of soy nutries and fried soy dhal: Sensory and nutritional evaluation. J. Food Sci. Technol., 45(1): 105-107.

D. Sarada and M.R. Mrudula, (2016) Millet pulse ladoo as a nutritional supplement for pre-school age (anganwadi) children. International Research Journal of Natural and Applied Sciences, Vol. 3, Issue 2, Feb 216.

Shanti Ghosh, (2006). Child rights: Integrated Child Development Services Programme, DPH Pvt. Ltd., New Delhi, 94.

\section{How to cite this article:}

Barkha Sharma, Jagdish Patidar, S. Tripaty and Pachaury, D.R. 2018. Assessment of Supplementation of Soy-Poha Ladoo for Prevention of Malnutrition in Rural Area of Ratlam District, India. Int.J.Curr.Microbiol.App.Sci. 7(12): 393-396.

doi: https://doi.org/10.20546/ijcmas.2018.712.049 